www.jmscr.igmpublication.org

Impact Factor 3.79

Index Copernicus Value: 5.88

ISSN (e)-2347-176x ISSN (p) 2455-0450

crossref DOI: _http://dx.doi.org/10.18535/jmscr/v4i02.69

Journal Of Medical Science And Clinical Research

\title{
Children with Severe Acute Malnutrition, Outcome and its Complications in Children admitted at tertiary level Centre (MTC) -A Prospective Study
}

Authors

\section{Dr Dinesh Kumar Meena ${ }^{1}$, Dr Dipendra Sharma ${ }^{2}$ Dr. Naresh Kumar Meena ${ }^{3}$, Dr Ankur Jain ${ }^{4}$}

${ }^{1}$ MD Pediatrics, Medical Officer Ex Resident, Pediatrics, Govt. Medical College Kota

${ }^{2}$ MD Pediatrics, Senior medical officer cum clinical tutor, J.K. Lone hospital, Govt. Medical College

Kota, Rajasthan, India

${ }^{3}$ Senior Resident, MD Pediatrics, Department of Pediatrics, J.K.Lone Hospital, Govt. Medical College Kota, Rajasthan, India.

${ }^{4}$ Assistant Professor, Dept of Pediatrics, J.K.Lone Hospital, Govt. Medical College Kota, Rajasthan, India

\section{ABSTRACT}

The present study was conducted in malnutrition treatment centre (MTC) at the department of paediatrics, Govt. Medical College, Kota for a period of one year from November 2012 to October 2013. A total of 54 (27 Male and 27 Female) patients were admitted during the study period, of which $57.41 \%$ had loss of appetite, and 50\% had anaemia, 46.30\% had diarrhea, 35.19\% had vomiting, $31.48 \%$ had acute respiratory tract infection, $12.96 \%$ had vitamin A deficiency, $11.11 \%$ had hypoglycaemia, Tuberculosis was diagnosed in $7.41 \%$ of cases. Odema were present in $7.41 \%$ cases, Malaria and Measles were diagnosed in $3.7 \%$ each, and dysentery was seen in $1.85 \%$ cases. Timely identification and treatment of various co-morbidities is likely to break under-nutrition- disease cycle, and to decrease mortality and improve outcome.

Key words: Co-morbidities, Diarrhea, Hospitalisation, India, Management, Severe acute malnutrition.

\section{INTRODUCTION}

Severe Acute Malnutrition affects nearly twenty million under five children, and contributes to one million child deaths yearly ${ }^{[1]}$. The mortality rate of children with complicated SAM that receive treatment in inpatient set ups has remained unacceptably high ${ }^{[2]}$. Such high mortality in inpatient units has been attributed to comorbidities such as infections and micronutrient deficiencies ${ }^{[3]}$.

There is a lack of systematic reporting of clinical and laboratory data taken on admission or during hospital stay to identify baseline risk factors that allow comparative studies of the burden, spectrum and outcome of co-morbidities of severe malnutrition. Here we present a description of comorbid findings in children admitted to a tertiary level hospital in central India.

\section{METHODS}

This Prospective study was carried out in the Department of Pediatrics, Govt. Medical College Kota from November 2012 to October 2013. Children between six to sixty months of age with severe acute malnutrition (SAM) admitted in the MTC in our hospital. WHO criteria were used to define severe acute malnutrition ${ }^{[4]}$. Children who have chronic malnutrition due to systemic illness 
and weight for height $>-3 \mathrm{SD}$ and age below 6 month were excluded. Detailed history and systemic examination were done and the clinical signs of micronutrient deficiencies were assessed; and frequencies of various co morbid conditions in study population were assessed.

Ethical Issues: A written, informed consent was obtained from parents. Clearance from Departmental Ethics Committee was taken prior to the start of the study. All participants had the option to withdraw from the study anytime during their hospital stay.

\section{RESULTS}

Out of 54 SAM children $(n=54), 27(50 \%)$ were females and 27(50\%) were male. out of which 28 $(51.9 \%)$ of patients were in age group six to twelve months and 19 (35.2\%) were in age group 13-24 months. Mean age of presentation was 16.81 months. The mean weight of children at admission was $5.88 \pm 1.59 \mathrm{~kg}$ and mean weight on discharge was $6.71 \pm 1.77 \mathrm{~kg}$. This was statistically significant $(\mathrm{t}=-14.55, \mathrm{p}<0.001)$. The Mean MUAC at admission was $10.62 \pm 1.21 \mathrm{~cm}$. and mean MUAC on discharge was $11.49 \pm 1.24 \mathrm{~cm}$. This was statistically significant $(\mathrm{t}=-13.87$, $\mathrm{p}<0.001)$.

At the time of admission 54(100\%) were severely malnourished i.e. were <-3 SD(20 Cases), <-4 $\mathrm{SD}(34$ Cases )(Weight for Height).After intervention in hospital about $65 \%$ of patients improve their health status and entered into ,-1 SD and <-2 Sd of weight for height. About $35 \%$ of children failed to improve their status even after an average $13.48 \pm 2.77$ days of hospital stay. Anaemia (50\%) and Diarrhea (46.30\%) was found to be the most common co morbid disease associated with SAM. Table 1 and 2 Show the detailed results.

Table. 1:- Analysis of the admitted children based on complications in male and female $(n=54)$

\begin{tabular}{|l|l|l|l|l|l|}
\hline S. No. & Complication & Male $(\mathrm{n}=27)$ & Female $(\mathrm{n}=27)$ & Total & Percent \\
\hline 1 & Loss of appetite & 14 & 17 & 31 & 57.41 \\
\hline 2 & Anaemia & 11 & 16 & 27 & 50.00 \\
\hline 3 & Diarrhea & 10 & 15 & 25 & 46.30 \\
\hline 4 & Vomiting & 6 & 13 & 19 & 35.19 \\
\hline 5 & ARTI & 9 & 8 & 17 & 31.48 \\
\hline 6 & Vitamin A deficiency & 3 & 4 & 7 & 12.96 \\
\hline 7 & Hypoglycemia & 1 & 5 & 6 & 11.11 \\
\hline 8 & Tuberculosis & 3 & 1 & 4 & 7.41 \\
\hline 9 & Oedema & 1 & 3 & 4 & 7.41 \\
\hline 10 & Malaria & 0 & 2 & 2 & 3.70 \\
\hline 11 & Measles & 0 & 2 & 2 & 3.70 \\
\hline 12 & Dysentry & 0 & 1 & 1 & 1.85 \\
\hline
\end{tabular}

Table.2:- Complications according to age group $(n=54)$

\begin{tabular}{|l|l|l|l|l|l|l|}
\hline Symptoms/ Complications & $\begin{array}{l}0-12 \\
\text { month }\end{array}$ & $\begin{array}{l}13-24 \\
\text { month }\end{array}$ & $\begin{array}{l}25-36 \\
\text { month }\end{array}$ & $\begin{array}{l}37-48 \\
\text { month }\end{array}$ & $\begin{array}{l}49-60 \\
\text { month }\end{array}$ & Total \\
\hline Loss of appetite & 9 & 15 & 3 & 2 & 2 & 31 \\
\hline Oedema & 1 & 1 & 1 & 0 & 1 & 4 \\
\hline Hypoglycemia & 1 & 3 & 0 & 0 & 2 & 6 \\
\hline Diarrhea & 14 & 7 & 1 & 1 & 2 & 25 \\
\hline Dysentry & 0 & 1 & 0 & 0 & 0 & 1 \\
\hline Vomiting & 10 & 7 & 0 & 0 & 2 & 19 \\
\hline ARTI & 9 & 7 & 1 & 0 & 0 & 17 \\
\hline Anaemia & 14 & 10 & 1 & 0 & 2 & 27 \\
\hline Malaria & 1 & 1 & 0 & 0 & 0 & 2 \\
\hline Measles & 1 & 1 & 0 & 0 & 0 & 2 \\
\hline Tuberculosis & 1 & 2 & 0 & 0 & 1 & 4 \\
\hline Vitamin A Deficiency & 2 & 2 & 1 & 0 & 2 & 7 \\
\hline
\end{tabular}




\section{DISCUSSION}

Mean age of children reporting with malnutrition are similar to other studies and there were no significant sex predominance in malnourished children ${ }^{(5)}$. Diarrhea and Anaemia were two most common co morbid diseases followed closely by Vomiting and ARTI in malnourished children admitted in our hospital. Previous studies have also reported that malnourished children suffer in greater proportion from bacterial gastrointestinal and respiratory infections ${ }^{[6]}$. Absence of a comparative group, no biochemical evaluation for micronutrient deficiencies and non-assessment of contributing factors for these deficiencies were the main lacunae of the study.

In a Colombian study, $68.4 \%$ of malnourished children were suffering from diarrhea and $9 \%$ had sepsis at the time of admission ${ }^{[7]}$. Two African studies also showed high incidence of diarrhea in SAM children $49 \%$ and $67 \%{ }^{[8,9]}$. Though previous reports have described malnutrition as an important risk factor for pneumonia than for diarrhea ${ }^{[10]}$, diarrhea was the major co morbid condition found in our study A study from Africa [11] also reported a comparable incidence of respiratory illness and tuberculosis (18\% each) in admitted SAM children. Measles has severe consequences on the nutritional status. A previous Indian study ${ }^{[12]}$ showed only 3- $4 \%$ of children with past history of measles but we found a higher proportion. Malaria were considered as major comorbidities with total prevalence of $21 \%$ and $29.2 \%$, respectively ${ }^{[11]}$ but data from our hospital showed a comparatively lesser incidence.

Overlapping nature of protein-energy malnutrition and micronutrient deficiencies were well understood and it is seen that lack of one micronutrient is typically associated with deficiencies of other ${ }^{[13]}$. Anaemia and Vitamin A deficiency were the two most common micronutrient deficiencies associated with malnutrition in our study, and this is consistent with the previous reports ${ }^{[14]}$. The high incidence of anaemia in these children could be due to nutritional factors as well as incident helminthic infections.
Other micronutrient deficiencies seen in this study have also been previously reported ${ }^{[15]}$.

\section{CONCLUSION}

Anaemia, Diarrhea, Vomiting, Respiratory tract infections and vitamin A deficiency are the most common co morbid conditions in admitted severe acute malnourished children in this region.

As revealed by findings the difference between the MUAC and mean weight of the study group at the time of admission and discharge was statistically significant. These findings clearly reflect a positive effect of the interventional measures on the admitted children.

Though the number of severely malnourished children decreased significantly at the time of discharge as compared to admission.

Apart from nutritional rehabilitation, timely identification and treatment of co-morbidities like diarrhea, acute respiratory tract infection, anemia and micronutrient deficiencies is vital in malnourished children, so as to break undernutrition-disease cycle, and to decrease mortality and to improve outcome.

\section{REFERENCES}

1. Black RE, Allen LH, Bhutta ZA, Caulfield LE, de Onis M, Ezzati M, et al. Maternal and child undernutrition: global and regional exposures and health consequences. Lancet .2008;371:243-60.

2. Heikens GT. How can we improve the care of severely malnourished children in Africa? PLoS Med. 2007;4: e45.

3. Heikens GT, Bunn J, Amadi B, Manary M, Chhagan M, Berkley JA, et al. Case management of HIV-infected severely malnourished children: challenges in the area of highest prevalence. Lancet. 2008;371:1305-7.

4. World Health Organization. Management of Severe Malnutrition: A Manual for Physicians and Other Senior Health Workers, World Health Organization, Geneva, Switzerland, 1998. 
5. Bachou H, Tylleskär $\mathrm{T}$, Deogratias $\mathrm{H}$, Mulindwa K, Tumwine JK. Bacteraemia among severely malnourished children infected and uninfected with the Human immunodeficiency virus-1 in Kampala, Uganda. BMC Infect Dis. 2006;6:160.

6. De Onis M, Monteiro C, Akré J, Clugston G. The worldwide magnitude of proteinenergy malnutrition: An overview from the WHO global database on child growth. Bull World Health Organ. 1993;71:703-12

7. Bernal C, Velásquez C, Alcaraz G, Botero J. Treatment of severe malnutrition in children: Experience in implementing the world health organization guidelines in turbo, Colombia. J Pediatr Gastroenterol Nutr. 2008;46:322-8.

8. KUMAR, et al. CO-MORBIDITIES IN SEVERELY MALNOURISHED CHILDREN INDIAN PEDIATRICS 5 AUGUST 5, 2013 [E-PUB AHEAD OF PRINTS]

9. Talbert A, Thuo N, Karisa J, Chesaro C, Ohuma E, Ignas $\mathrm{J}$, et al. Diarrhoea complicating severe acute malnutrition in Kenyan children: A prospective descriptive study of risk factors and outcome. PLoS ONE. 2012; 7: p1.

10. Irena AH, Mwambazi M, Mulenga V. Diarrhea is a major killer of children with severe acute malnutrition admitted to inpatient set-up in Lusaka, Zambia. Nutrition J. 2011;10:110.

11. Berkowitz FE. Infections in children with severe protein-energy malnutrition. Pediatr Infect Dis J. 1992;11:750-9.

12. Sunguya BF, Koola JI, Atkinson S. Infections associated with severe malnutrition among hospitalised children in East Africa. Tanzania Health Research Bulletin. 2006;8: 189-92.
13. Bhaskaram P. Measles and malnutrition. Indian J Med Res. 1995;102:195-99.

14. Olaf Müller, Michael Krawinkel. Malnutrition and health in developing countries CMAJ. 2005;173:279-86.

15. Ejaz MS, Latif N. Stunting and micronutrient deficiencies in malnourished children. J Pak Med Assoc. 2010;60:5437.

16. Chainani N, Sharma P, Meena N, Sharma U. Pattern of vitamin deficiencies among the malnourished preschool children in ICDS blocks of Jaipur city. Indian J Matern Child Health. 1994;5:109-11. 